Whitaker, D. M., P. D. Taylor, and I. G. Warkentin. 2015. Gray-cheeked Thrush (Catharus minimus minimus) distribution and habitat use in a montane forest landscape of western Newfoundland, Canada. Avian Conservation and Ecology 10(2):4. http://dx.doi.org/10.5751/ACE-00778-100204 Copyright (C) 2015 by the author(s). Published here under license by the Resilience Alliance.

\title{
Gray-cheeked Thrush (Catharus minimus minimus) distribution and habitat use in a montane forest landscape of western Newfoundland, Canada
}

\author{
Darroch M. Whitaker ${ }^{1}$, Philip D. Taylor ${ }^{2}$ and Ian G. Warkentin ${ }^{3}$ \\ ${ }^{1}$ Parks Canada, ${ }^{2}$ Acadia University, ${ }^{3}$ Memorial University of Newfoundland
}

\begin{abstract}
Once abundant, the Newfoundland Gray-cheeked Thrush (Catharus minimus minimus) has declined by as much as 95\% since 1975. Underlying cause(s) of this population collapse are not known, although hypotheses include loss of winter habitat and the introduction of red squirrels (Tamiasciurus hudsonicus) to Newfoundland. Uncertainties regarding habitat needs are also extensive, and these knowledge gaps are an impediment to conservation. We investigated neighborhood (i.e., within $115 \mathrm{~m}$ [4.1 ha]) and landscape scale (i.e., within $1250 \mathrm{~m}$ [490.8 ha]) habitat associations of Gray-cheeked Thrush in a 200-km² study area in the Long Range Mountains of western Newfoundland, where elevations range from 300-600 m and landcover was a matrix of old growth fir forest, 6- to 8-yearold clearcuts, coniferous scrub, bogs, and barrens. Thrushes were restricted to elevations above $\sim 375 \mathrm{~m}$, and occurrence was strongly positively related to elevation. Occurrence was also positively related to cover of tall scrub forest at the neighborhood scale, and at the landscape scale showed curvilinear relations with the proportion of both tall scrub and old growth forest that peaked with intermediate amounts of cover. Occurrence of thrushes was also highest when clearcuts made up $60 \%-70 \%$ of neighborhood landcover, but was negatively related to cover of clearcuts in the broader landscape. Finally, occurrence was highest in areas having $50 \%$ cover of partially harvested forest (strip cuts or row cuts) at the neighborhood scale, but because this treatment was limited to one small portion of the study area, this finding may be spurious. Taken together, our results suggest selection for mixed habitats and sensitivity to both neighborhood and landscape-scale habitat. More research is needed on responses of thrushes to forestry, including use of older clearcuts, partially harvested stands, and precommercially thinned clearcuts. Finally, restriction of thrushes to higher elevations is consistent with the hypothesis that they have been impacted by squirrels, because squirrels were rare or absent at these elevations.
\end{abstract}

\section{Répartition et utilisation de l'habitat chez la Grive à joues grises (Catharus minimus minimus) dans un paysage forestier en altitude dans l'ouest de Terre-Neuve, Canada}

RÉSUMÉ. Autrefois abondante, la Grive à joues grises de Terre-Neuve (Catharus minimus minimus) a diminué de $95 \%$ depuis 1975. La ou les causes sous-jacentes à l'effondrement de cette population sont inconnues, bien que les pertes d'habitat sur les aires d'hivernage et l'introduction de l'écureuil roux (Tamiasciurus hudsonicus) sur l'île de Terre-Neuve fassent partie des hypothèses avancées. Les incertitudes quant aux besoins en matière d'habitat sont également considérables et représentent des obstacles pour la conservation. Nous avons examiné les associations de la grive avec l'habitat à l'échelle locale (c.-à-d. à l'intérieur de $115 \mathrm{~m}$ [4,1 ha]) et à celle du paysage

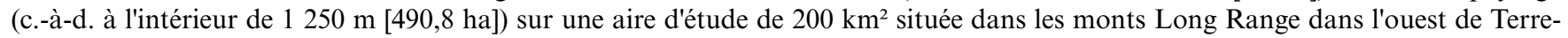
Neuve, où l'altitude varie de 300 à $600 \mathrm{~m}$ et le couvert forestier est constitué d'une matrice de vieilles forêts de sapins, de coupes totales âgées de 6 à 8 ans, d'arbustes conifériens, de tourbières ombrotrophes et de landes. Les grives étaient restreintes aux altitudes au-dessus de $\sim 375$ m et leur occurrence était fortement associée positivement avec l'altitude. Leur occurrence était aussi positivement associée aux peuplements de grands arbustes à l'échelle locale; à l'échelle du paysage, l'occurrence montrait des relations curvilignes avec la proportion de grands arbustes et de vieilles forêts et culminait en présence de valeurs intermédiaires de ces deux types forestiers. L'occurrence des grives était aussi maximale lorsque les coupes totales comptaient pour 60 à $70 \%$ de la couverture terrestre locale, mais était négativement associée aux parterres de coupes totales à l'échelle du paysage. Enfin, l'occurrence était le plus élevée dans les endroits qui comportaient $50 \%$ de couvert forestier partiellement récolté (coupes par bande ou par rangée) à l'échelle locale, mais étant donné que ce traitement était limité à une seule petite partie de l'aire d'étude, ce résultat pourrait se révéler faux. Pris dans leur ensemble, nos résultats semblent indiquer que les grives sélectionnent des milieux mixtes et montrent une sensibilité à l'habitat tant à l'échelle locale qu'à celle du paysage. De plus amples recherches sont nécessaires pour comprendre comment les grives réagissent face à l'aménagement forestier, y compris l'occupation des vieilles coupes totales, des peuplements partiellement récoltés et des coupes d'éclaircies précommerciales. En conclusion, le fait que les grives soient restreintes à des altitudes plus élevées est en accord avec l'hypothèse voulant qu'elles aient été affectées par la compétition avec les écureuils, parce que les écureuils étaient rares, voire absents, à ces altitudes.

Key Words: balsam fir; Catharus minimus; clearcut; elevation; forestry; Gray-cheeked Thrush; habitat; landscape; Newfoundland; old growth; red squirrel 


\section{INTRODUCTION}

The Gray-cheeked Thrush (Catharus minimus) is a Neotropical migrant passerine that breeds in northern boreal "taiga" forests and low-Arctic shrub thickets across North America and into eastern Siberia (Lowther et al. 2001). Two subspecies are recognized on the basis of subtle differences in plumage and morphology, the Northern Gray-cheeked Thrush (Catharus minimus alicia), breeding from central Labrador west to Siberia, and the Newfoundland Gray-cheeked Thrush (Catharus minimus minimus; Fig. 1), which breeds on the island of Newfoundland and possibly adjacent portions of southern coastal Labrador and the Quebec North Shore (Lowther et al. 2001). Though once abundant throughout most of Newfoundland, Breeding Bird Survey (BBS; Sauer et al. 2014) data indicate that Gray-cheeked Thrush numbers on the island have declined by as much as $95 \%$ since 1975 (SSAC 2010; see also Environment Canada 2014), and C. m. minimus is now listed as threatened under the Newfoundland and Labrador Endangered Species Act. Although this decline has been dramatic, little is known about its underlying causes. Loss or degradation of wintering habitat has been suggested as a possible factor, but the winter range of $C$. m. minimus is not well understood, so this hypothesis is speculative (SSAC 2010). The introduction of red squirrels (Tamiasciurus hudsonicus) to the island of Newfoundland may also have had an impact on the thrush population. Squirrels were introduced during the 1960s (Payne 1976, Dodds 1983) and following a series of translocations during the 1970s, became widespread during the 1980s and early 1990s (Minty 1976, Goudie 1978; D. M. Whitaker, unpublished manuscript). This coincides with the period of steepest decline in thrush numbers (SSAC 2010, see also Whitford 1993), and red squirrels, which have been reported to cause nesting failure in the closely related Bicknell's Thrush (Catharus bicknelli; McFarland et al. 2008), are now the dominant predator of bird's nests on Newfoundland (Lewis 2004). Other possible contributing factors include forest harvesting and competition from Swainson's Thrushes (Catharus ustulatus), although their potential influence seems secondary at best. Although industrial forestry has been extensive in Newfoundland, it has been ongoing for more than 100 years, whereas the decline of Gray-cheeked Thrushes occurred very rapidly in the past 40 years. Further, many of the habitats used by the thrushes are either unaffected by forestry (e.g., conifer scrub) or are created by it (e.g., clearcuts), and the thrushes have also declined in large protected areas having no large-scale forestry. Competition with Swainson's Thrushes has been suggested because it may be a factor affecting Bicknell's Thrushes (e.g., Lambert et al. 2005), but numbers of Swainson's Thrushes have been relatively stable on Newfoundland throughout the decline of Gray-cheeked Thrushes (Environment Canada 2014) so it seems unlikely that competition has increased dramatically.

Gray-cheeked Thrushes have been little studied and the species' habitat needs are poorly understood throughout its range (Lowther et al. 2001). Across its northern breeding grounds, this thrush is typically associated with low coniferous and deciduous thickets having a high density of woody stems $\sim 2-6 \mathrm{~m}$ tall (Lowther et al. 2001). These include willow and alder thickets, regenerating coniferous stands, scrub conifer forests, stunted Krummholtz, and open canopy forests having a dense understory. In Newfoundland the Gray-cheeked Thrush has been reported to have a more pronounced affinity to conifer scrub than elsewhere in its range
(Marshall 2001). However, it has also been found to breed in old growth balsam fir (Abies balsamea) forests of western Newfoundland, where canopy heights average nearly $12 \mathrm{~m}$ (Thompson et al. 1999). At the root of this latter association may be the fact that the gap-dynamic structure of old growth fir stands in western Newfoundland, combined with the propensity for balsam fir to produce a standing stock of advanced regeneration, leads to the development of high densities of fir saplings and deciduous shrubs in the understory (McCarthy and Weetman 2006). Additionally, in western Newfoundland these old growth stands typically occur in a landscape matrix that includes large patches of scrub forest associated with poor or saturated soils and windswept hilltops. As with many other boreal forest birds (e.g., Leonard et al. 2008, Whitaker and Warkentin 2010), individual Gray-cheeked Thrushes may range widely and so be able to effectively exploit a patchy landscape matrix such as this.

Fig. 1. Newfoundland Gray-cheeked Thrush (Catharus minimus minimus) banded in the Main River Watershed. C. $m$. minimus is typically browner overall and has a buffier wash to the breast than the Northern Gray-cheeked Thrush (C. $m$. aliciae), and also has a more extensive, brighter yellow area at the base of the lower mandible. (Photo by D. Whitaker)

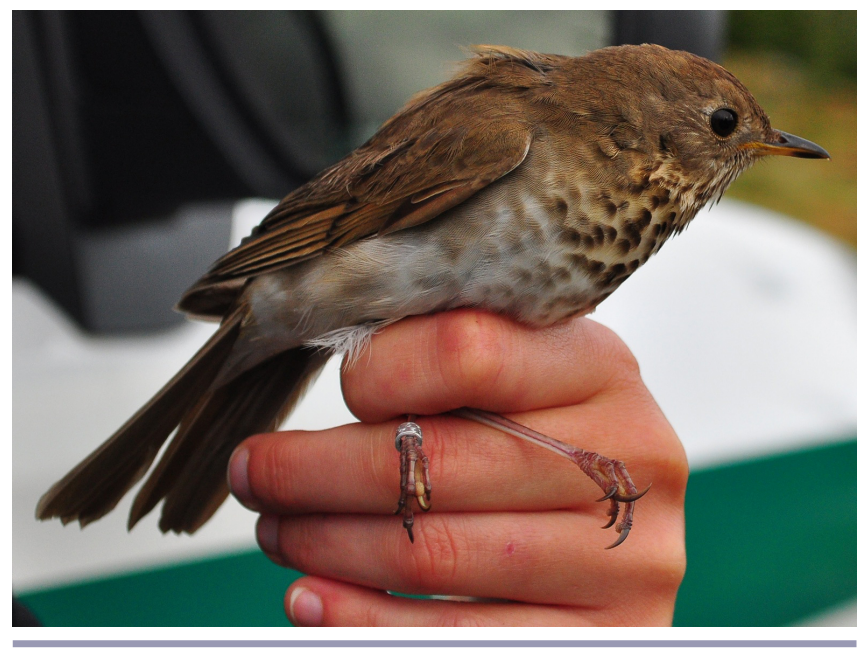

Beyond the aforementioned general observations, little quantitative information is available on habitat use by Graycheeked Thrushes in Newfoundland. Thompson et al. (1999) reported that they are a characteristic species in stands of virgin old growth balsam fir forest ( $>80$ years old) of western Newfoundland, but are absent from 40- to 80-year-old second growth stands. However that study did not consider other landcover types or landscape-scale factors. Marshall (2001) searched extensively for the species in western Newfoundland and found it in both scrub forests and mature conifer forests, and reported that it was erratic in its distribution, with local populations being separated by large areas of seemingly suitable habitat. Similarly, Vassallo and Rice (1981) reported that Graycheeked Thrushes were almost two times more common on a nearshore island than on the adjacent "mainland" of Newfoundland, even though both sites supported similar coastal fir and spruce forest cover. Lamberton (1976) reported that the species was abundant in the conifer scrub and high-elevation old growth fir 
forests of Gros Morne National Park. However, Gray-cheeked Thrushes had largely disappeared from the lowland scrub forest in the park when Lamberton's plots were resampled in 1992 (Whitford 1993).

Because of its northern breeding distribution, habitat of the Graycheeked Thrush is considered to be secure and at limited risk from anthropogenic disturbance throughout most of its breeding range (Lowther et al.2001). However Newfoundland lies at the southern limit of the species' breeding range, and forests on the island have been subjected to large-scale industrial logging since the early 1900s. Although this has not been identified as a key driver of the decline of Gray-cheeked Thrushes on the island, any influence of forest management (positive or negative) may be important to their future conservation and recovery. For example, industrial forest management has led to concern over loss of old growth balsam fir forest on the island (e.g., Thompson 1991, Thompson et al. 2003). Although this concern may be reduced at present because of a downturn in the pulp and paper industry and because the province has put measures in place to safeguard old growth forests (Government of Newfoundland and Labrador 2014), there is a need to assess the importance of old growth forests to these thrushes. Also, the ecology of Gray-cheeked Thrushes shows many similarities to that of the closely related Bicknell's Thrush, which was considered to be a third subspecies of Graycheeked Thrush until 1995 (Rimmer et al. 2015). Bicknell's Thrushes make extensive use of young fir stands that regenerate after clearcutting or natural forest succession, with abundance peaking 11-13 years postdisturbance (Nixon et al. 2001, Rimmer et al. 2015, Chisholm and Leonard 2008, Aubry et al. 2011); however, the use of dense, regenerating clearcuts by Gray-cheeked Thrushes has not been studied. Consequently, there is a need for locally relevant information on the habitat requirements of Graycheeked Thrushes in Newfoundland, in particular their response to forest management.

During 2006 and 2007 we systematically surveyed a $200 \mathrm{~km}^{2}$ landscape for Gray-cheeked Thrush as part of ongoing research into landscape-scale effects of forest management on birds in western Newfoundland (see also Taylor and Krawchuk 2005, Leonard et al. 2008, Whitaker et al. 2008, Dalley et al. 2009, Mitchell et al. 2009, 2010). Here we present an analysis of the distribution and local and landscape-scale habitat associations of Gray-checked Thrushes and discuss this in the context of hypotheses about the decline of the Newfoundland population, interactions with forest management, and future research needs.

\section{METHODS}

Research was conducted in the upper reaches of the Main River and Humber River watersheds, situated on the eastern slope of the Long Range Mountains in western Newfoundland, Canada ( $57^{\circ} 15^{\prime} \mathrm{W}$; $49^{\circ} 45^{\prime} \mathrm{N}$; elevation range $300-600 \mathrm{~m}$; Fig. 2 ). The study landscape is a naturally heterogeneous mosaic that had been recently modified by industrial timber harvesting; during this study land cover was comprised of approximately $8 \%$ surface water; $11 \%$ bogs, barrens, and other natural openings; $36 \%$ scrub forest; $40 \%$ second growth and old growth forest; and $6 \%$ clearcut forest. Timber harvesting occurred during 1999 and 2000, so clearcuts were 6-8 years old and ranged in size from 20 to 100 ha, whereas natural forest openings ranged in size from 1 to 50 ha. Two modified timber harvest blocks were also present in the northwest portion of the study area: a row cut created in 2001 (152 ha) and a strip cut created in 2003 (145 ha; Fig. 3). Both of these modified harvest blocks would have had a more open or fragmented canopy than is typical of intact forest stands, and as a result may have had more growth in the understory. Both productive and scrub forests in the region are typically dominated by balsam fir, with a significant representation of black spruce (Picea mariana), particularly on wet soils, and white birch (Betula papyrifera) on well-drained sites (McCarthy and Weetman 2006). Most of the study area had never been logged, and wildfire and stand-killing outbreaks of defoliating insects have been rare because of the wet climate and cold winters. This lack of recent large-scale disturbance leads to a prevalence of gap-dynamic old growth balsam fir forests on productive sites (McCarthy and Weetman 2006).

Fig. 2. Distribution of survey points in the upper Main River and Humber River watersheds in western Newfoundland. Points sampled in 2006 are depicted with circles, while those sampled in 2007 are illustrated using squares. Points where Gray-cheeked Thrushes (Catharus minimus minimus) were observed are depicted with pink circles (2006) and blue squares (2007). Clearcuts are depicted in orange, and modified harvest blocks are shown in purple. The red box on the inset map shows the location of the study area on the island of Newfoundland, and Gros Morne National Park is depicted in green.

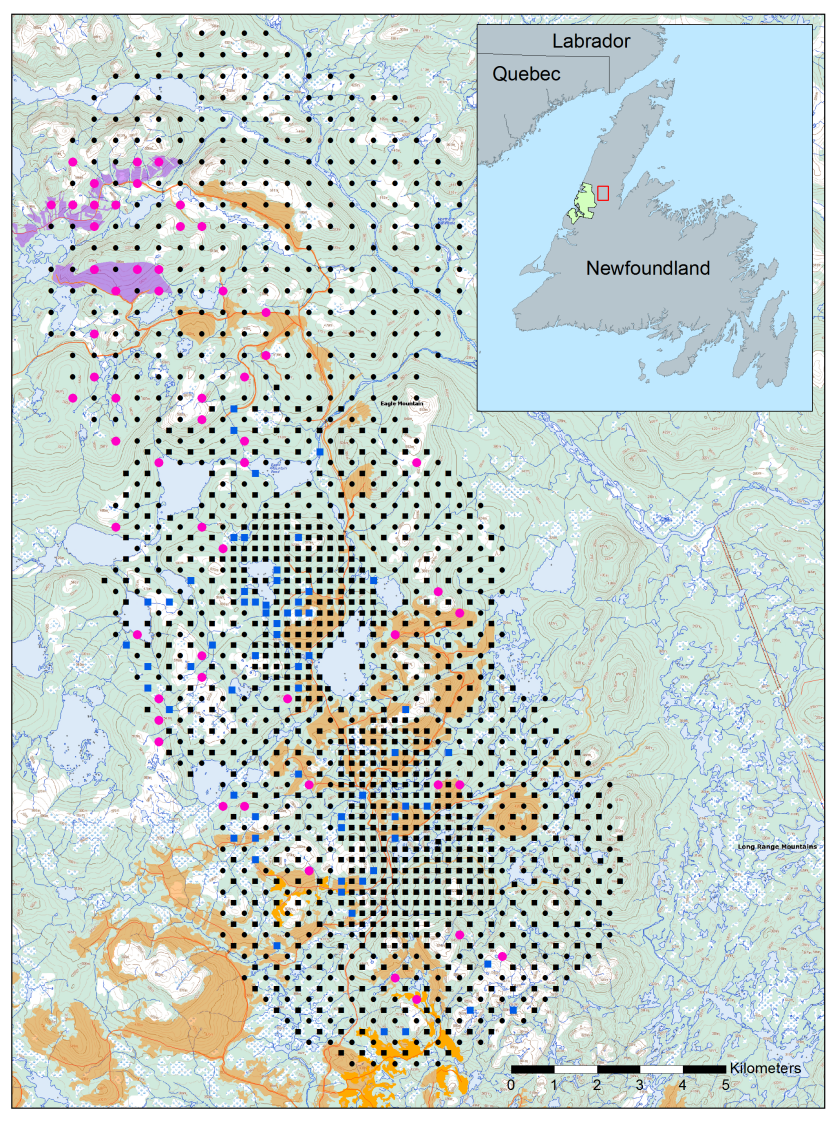


Fig. 3. A modified harvest block (strip cut) in old growth forest in the northwest portion of the study area. Gray-cheeked Thrushes (Catharus minimus minimus) were observed at three of four survey points in this block. Note that this photo was taken in June 2005, so some additional vegetation growth would have occurred in the strip cuts prior to the initiation of thrush surveys in June 2006. (Photo by D. Whitaker)

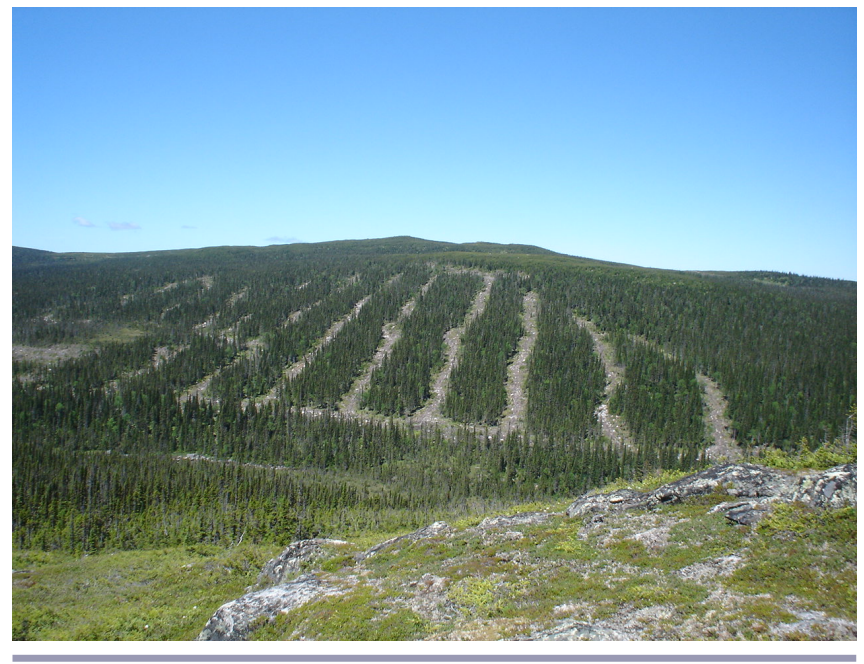

During 2006, bird surveys were conducted across a $200 \mathrm{~km}^{2}$ systematic grid of 812 survey points spaced at $500-\mathrm{m}$ intervals (Fig. 2). During 2007 the grid design was modified because the northern third of the sampling area had been rendered inaccessible by the removal of the bridge crossing a large river. Instead, the southern two thirds of the study area was resampled using a similar base grid of points spaced at 500-m intervals, with additional effort being allocated to sampling points spaced at 250$\mathrm{m}$ intervals in the central portion of the survey area $(n=801$ survey points). In 2007 the base grid was also shifted $250 \mathrm{~m}$ north and $250 \mathrm{~m}$ east, such that points surveyed in the second year were located midway between those sampled the previous year (Fig. 2).

Our data were collected in conjunction with a resighting survey for color-banded birds of six other focal species: Hermit Thrush (Catharus guttatus), Yellow-rumped Warbler (Setophaga coronata), Blackpoll Warbler (Setophaga striata), Northern Waterthrush (Parkesia noveboracensis), Fox Sparrow (Paserella iliaca), and White-throated Sparrow (Zonotrichia albicollis). Observers were equipped with binoculars and avoided wearing brightly colored clothing (Riffell and Riffell 2002). Surveys were conducted between 0530 and $1700 \mathrm{~h}$ each day and ran from the first week of June until the third week of July each year. To increase the likelihood of observing birds, we used playbacks of Black-capped Chickadee (Poecile atricappillus) predator mobbing calls as well as conspecific song and vocalizations of all seven focal species (Gunn et al. 2000, Betts et al. 2005, Rae et al. 2015). Gray-cheeked Thrushes are furtive and erratic in their singing and calling (Lowther et al. 2001, Marshall 2001), and this approach can be useful for increasing visual detections of such species and also for reducing variation in detection rates associated with time of day or time of season (Rae et al 2015; Darroch M. Whitaker, unpublished data). On arriving at a station, an observer silently looked and listened for birds for one minute and then broadcast a series of bird recordings that began with a five-minute recording of chickadee predator mobbing calls followed by a series of two-minute recordings of each focal species' calls and territorial song, ending with Gray-cheeked Thrush. The volume control of broadcasting units was set at a constant level for all surveys, and when measured $1 \mathrm{~m}$ from the speaker the average volume of chickadee playbacks was $81.5 \mathrm{~dB}$, with peak volumes of $92.7 \mathrm{~dB}$ (see also Rae et al. 2015). Use of conspecific playbacks is a strong attractant for territorial songbirds, especially males, during the breeding season (Betts et al. 2005). Consequently we presume that our detection rate was high and did not attempt to control for detection probability during our analyses. Similarly, detection rates using playbacks were consistent throughout the day and also throughout our survey period, so we did not control for time of day or season date. Resightings of color-banded individuals of our six other focal species also indicated that there was a high degree of independence between adjacent survey points; even though surveyors sequentially sampled adjacent points each day, only $5 \%$ of color-banded individuals encountered (9/181) were observed at multiple stations on the same day, and most of these (7/9) were seen at points located $250 \mathrm{~m}$ apart. Thus, the incidence of individual birds being drawn from point to point by playbacks was low, possibly because they could not hear playbacks broadcast at subsequent stations. However, songbirds also typically only respond aggressively to conspecific vocalizations within their territory (Betts et al. 2005), and territories of most species are relatively small compared with the scale of our sampling (Whitaker and Warkentin 2010).

Because we were using recordings as an attractant to increase detections of birds, we did not attempt to relate detections to microscale habitat features at each survey point. However we presume that individuals responding to playbacks are by definition within their home range, i.e., the area within which they travel and perceive and respond to stimuli (sensu Powell 2000; see also Whitaker and Warkentin 2010). Songbirds also are likely to be within their defended territory (Betts et al. 2005), so analyses of habitat associations at broader scales are valid. Ideally we would have defined the scales at which we then assessed thrush habitat associations based on direct measurements of space use by Gray-cheeked Thrushes, but no such information was available at the time of this study (e.g., Lowther et al. 2001). Instead we followed a standard set by Leonard et al. (2008) and assessed habitat associations at neighborhood and landscape scales, i.e., within $115 \mathrm{~m}$ (4.1 ha) and $1250 \mathrm{~m}$ (490.8 ha) of each bird survey point, respectively. Leonard et al. (2008) identified these scales as approximating territory $(115 \mathrm{~m})$ and home range-scale habitat use $(1250 \mathrm{~m})$ via a study of space use by radio-tracked songbirds that was carried out in the same study area as this project. These scales are also in line with typical territory sizes and the scale of extraterritorial movements for temperate and boreal forest songbirds (Whitaker and Warkentin 2010). Note that for consistency with Leonard et al. (2008) we use the term "landscape scale" to refer to habitat within $1250 \mathrm{~m}$, which we consider to be the matrix of habitat patches and any nearby territories that are available to and potentially visited by individual birds during their daily movements (see also Lee et al. 2002, Betts et al. 2014). However other authors may refer to this as a meso scale and feel 
Table 1. Explanatory landcover variables used to assess habitat use by Gray-cheeked Thrushes (Catharus minimus minimus) in the upper Main River watershed, Newfoundland, 2006-2007. The mean and range of observations of percent cover or linear amount of each class occurring within $115 \mathrm{~m}$ and $1250 \mathrm{~m}$ of 1613 survey points is listed in the third and fourth columns, respectively. Note that three geographic variables were also evaluated: elevation (Elv; range $=300-600 \mathrm{~m}$ ), slope (Slope; range 0-60 $)$, and slope position $(\mathrm{S}$. Pos; bottom, midslope, or ridge).

\begin{tabular}{lllcc}
\hline \hline Landcover class & Code & Description & Mean $(115 \mathrm{~m})[\mathrm{range}]$ & Mean $(1,250 \mathrm{~m})[\mathrm{range}]$ \\
\hline Clearcut & Cc & Clearcuts (6-8 years-old) & $11.9 \%[0.0-100 \%]$ & $11.9 \%[0.0-54.7 \%]$ \\
Modified harvest & MH & Strip cuts and row cuts & $0.8 \%[0.0-100 \%]$ & $0.7 \%[0.0-31.6 \%]$ \\
Second Growth Forest & SGF & 20-80 year old conifer forest & $2.2 \%[0.0-100 \%]$ & $2.1 \%[0.0-25.1 \%]$ \\
Old Growth Forest & OGF & $>80$ year old conifer forest & $35.7 \%[0.0-100 \%]$ & $34.2 \%[10.2-75.1 \%]$ \\
Low scrub & LSc & Scrub forest $<6.5 \mathrm{~m}$ tall & $10.3 \%[0.0-100 \%]$ & $10.4 \%[0.0-38.5 \%]$ \\
Tall scrub & TSc & Scrub forest 6.5-12.5 m tall & $21.9 \%[0.0-99 \%]$ & $21.4 \%[4.4-48.4 \%]$ \\
Shoreline & ShL & Length of shoreline & $91 \mathrm{~m}[0-1096 \mathrm{~m}]$ & $10,170 \mathrm{~m}[849-31,000 \mathrm{~m}]$ \\
\hline
\end{tabular}

that a true landscape-scale study would evaluate the broader areas used by entire populations, including many individuals (e.g., Whitaker et al. 2006).

Neighborhood and landscape-scale habitat information associated with each survey point was obtained from a Geographic Information System (GIS) database developed by Parks Canada (Rocky Harbour, Newfoundland and Labrador, Canada). In this database, landcover was mapped according to the standard forest classification scheme used in the province of Newfoundland and Labrador, which assigned landscape elements to a variety of cover types (e.g., forest, bog, barren, water) and further identified forest stands according to 20-year age classes and dominant tree species composition. Patches of scrub forest were classified according to five height classes. A literature review of Gray-cheeked Thrush habitat associations, knowledge of forest dynamics in the study landscape, and data visualizations was then used to aggregate classes according to the simplified habitat classification scheme listed in Table 1. We also considered three geographic variables for each sampling point: elevation, which was taken from a digital elevation model, and slope (degrees) and slope position (ridge, midslope, or bottom), which were recorded in the field.

We used information-theoretic model selection to evaluate patterns of habitat use by Gray-cheeked Thrushes (Burnham and Anderson 2002), with all analyses being carried out using the $\mathrm{R}$ statistical package (R Development Core Team 2015). First we tested the pool of candidate explanatory variables for collinearity (Zuur et al. 2009). We then specified a set of a priori candidate models to evaluate patterns of habitat selection based on our knowledge of the study area and Gray-cheeked Thrush habitat use, as well as questions of interest (e.g., related to use of managed habitats). We followed a hierarchical approach when developing candidate models, specifying models that contained combinations of the following groups of explanatory variables: (1) models containing geographic variables only, (2) models containing neighborhood-scale landcover variables only, (3) models containing geographic and neighborhood-scale landcover variables, (4) models having neighborhood-scale and landscapescale landcover variables, and (5) models having geographic, neighborhood-scale and landscape-scale landcover variables. We did not specify models having only landscape-scale landcover variables because we presumed that birds select habitat in a hierarchical fashion and so are most sensitive to habitat occurring locally (sensu Johnson 1980) In total the a priori set included 238 models, which may seem excessive but was necessary given the number of explanatory variables being evaluated and the hierarchical approach being taken. To remove any potential difference in occurrence of thrushes between 2006 and 2007, we included year as a factor in all models. To evaluate the explanatory ability of our models, we also specified a null model, which contained year as the only explanatory variable. We then fit each candidate model to a Generalized Additive Model having a binomial error distribution and with occurrence of Gray-cheeked Thrush at each survey point, i.e., observed or not observed, specified as the response variable (R package mgcv, Wood 2011). In these models all continuous explanatory variables were fit as smoothed nonparametric splines to allow for and describe nonlinear relations, and we specified a clog-log link function, which typically performs better when the ratio of presence to absence is not approximately equal (Zuur et al. 2009). We then ranked the candidate models based on Akaike's Information Criterion adjusted for small sample sizes $\left(\mathrm{AIC}_{\mathrm{c}}\right)$ and calculated $\operatorname{AIC}_{c}$ differences $\left(\Delta_{\mathrm{i}}\right)$ relative to the model having the lowest $\mathrm{AIC}_{\mathrm{c}}$, model weights $\left(\omega_{i}\right)$, and predictor importance or weights (Burnham and Anderson 2002, Symonds and Mousalli 2011; R package MuMIn, Bartoń 2015). We then identified our 95\% confidence set of best models by ranking the models from highest to lowest model weight and including additional models until the cumulative model weight reached 0.95 (Symonds and Mousalli 2011).

\section{RESULTS}

Over the course of our surveys during 2006 and 2007, we observed Gray-cheeked Thrushes at 119 out of 1613 survey points $(7.4 \%$; Fig. 2); on 12 occasions 2 thrushes were observed at a survey point, whereas lone individuals were observed at the remaining 107 points. Collinearity between pairs of explanatory variables was limited, so no corrective steps were taken and all candidate variables were considered in developing a priori models. Although our a priori set included 238 models, after model fitting the $95 \%$ confidence set retained just 10 models (Table 2). All models in the $95 \%$ confidence set included geographic, neighborhood-scale landcover, and landscape-scale landcover terms, and had $\mathrm{AIC}_{\mathrm{c}}$ values that were $>106$ lower than the null model, indicating a large improvement in explanatory power. All models in the best model 
Table 2. Best model set (i.e., models having cumulative weights summing to 0.95) to explain habitat use by Gray-cheeked Thrushes (Catharus minimus minimus) in the Main River watershed in western Newfoundland, 2006-2007. The importance of individual explanatory variables, which represents the sum of the weights of all models containing each term, as well as the number of models containing each explanatory variable, are presented at the bottom. See Table 1 for descriptions of explanatory variables.

\begin{tabular}{|c|c|c|c|c|c|c|c|c|c|c|c|c|c|c|c|c|c|c|c|c|c|c|c|}
\hline \multirow[b]{2}{*}{ Rank } & \multirow[b]{2}{*}{ Year } & \multicolumn{3}{|c|}{ Geographic $^{\dagger}$} & \multicolumn{7}{|c|}{ Neighborhood Landcover $(115 \mathrm{~m})^{\dagger}$} & \multicolumn{7}{|c|}{ Landscape Landcover $(1,250 \mathrm{~m})^{\dagger}$} & \multicolumn{5}{|c|}{ Model statistics } \\
\hline & & Elv & S.Pos & Slope & LSc & $\mathrm{TSc}$ & OGF & SGF & ShL & $\mathrm{Cc}$ & $\mathrm{MH}$ & $\mathrm{LSc}$ & $\mathrm{TSc}$ & OGF & SGF & ShL & $\mathrm{Cc}$ & $\mathrm{MH}$ & $\mathrm{df}$ & $\log L$ & $\mathrm{AIC}_{\mathrm{c}}$ & $\Delta_{\mathrm{i}}$ & $\omega_{i}$ \\
\hline 1 & + & + & + & & & + & & & & + & + & & + & + & & + & + & & 22.63 & -347.5 & 741.0 & 0.0 & 0.21 \\
\hline 2 & + & + & & & & + & & & & + & + & & + & + & & + & + & & 20.81 & -349.6 & 741.4 & 0.4 & 0.17 \\
\hline 3 & + & + & + & & + & + & & & & + & + & + & + & + & & + & + & & 26.72 & -343.6 & 741.5 & 0.5 & 0.16 \\
\hline 4 & + & + & & & & + & & & & + & + & & + & + & + & + & + & & 24.98 & -345.7 & 742.2 & 1.2 & 0.11 \\
\hline 5 & + & + & & & & + & & & & + & + & & + & + & + & + & + & & 24.98 & -345.7 & 742.2 & 1.2 & 0.11 \\
\hline 6 & + & + & & & + & + & & & & + & + & + & + & + & & + & + & & 24.60 & -346.3 & 742.5 & 1.5 & 0.10 \\
\hline 7 & + & + & & & + & + & & + & & + & + & + & + & + & & + & + & & 25.75 & -346.1 & 744.5 & 3.5 & 0.04 \\
\hline 8 & + & + & & & & + & & & & + & + & & + & + & & & + & & 17.10 & -355.6 & 745.9 & 4.9 & 0.02 \\
\hline 9 & + & + & & & + & + & & + & & + & + & + & + & + & + & + & + & & 27.90 & -344.5 & 745.9 & 4.9 & 0.02 \\
\hline 10 & + & + & + & & & + & & & & + & + & & + & + & & & + & & 19.17 & -353.9 & 746.7 & 5.7 & 0.01 \\
\hline Null & + & & & & & & & & & & & & & & & & & & 2.00 & -424.2 & 852.9 & 111.9 & 0.00 \\
\hline Importance & & 1.00 & 0.41 & 0.00 & 0.35 & 1.00 & 0.00 & 0.06 & 0.02 & 1.00 & 1.00 & 0.35 & 1.00 & 1.00 & 0.24 & 0.92 & 1.00 & 0.00 & & & & & \\
\hline $\mathrm{n}($ models $)$ & 239 & 80 & 53 & 55 & 157 & 134 & 136 & 27 & 25 & 127 & 109 & 101 & 93 & 112 & 19 & 33 & 74 & 12 & & & & & \\
\hline
\end{tabular}

set included elevation; the amount of tall scrub, clearcut, and modified forest harvesting within $115 \mathrm{~m}$; and the amount of tall scrub, old growth forest, and clearcut within $1250 \mathrm{~m}$. The best model also included slope position and the amount of shoreline within $1250 \mathrm{~m}$ (Table 2, Fig. 4).

The single strongest predictor of the occurrence of Gray-cheeked Thrush in our study area was elevation, where there was a steep linear increase in the probability of observing thrushes with increasing elevation (Fig. 4). This pattern is clearly evident in a plot of the raw data: no thrushes were detected below 375-m elevation, and the percentage of points where thrushes were observed increased steadily from $\sim 1 \%$ of points between 375 and $400 \mathrm{~m}$ up to $20 \%$ of points between 575 and $600 \mathrm{~m}$, the highest elevations sampled (Fig. 5). Regarding the other geographic terms we evaluated, there was moderate support for the inclusion of slope position in models $\left(\omega_{i}=0.41\right.$; Table 2$)$, and in the best model the fit of this term indicated that the probability of occurrence of thrushes was lowest on ridges, intermediate on midslopes, and highest in bottoms. There was no support for an effect of slope angle on occurrence of thrushes.

There was strong support for an influence of tall scrub ( $>6.5 \mathrm{~m}$ tall) on the occurrence of thrushes. At the neighborhood scale our models suggested a strong linear increase in the occurrence of thrushes with increasing cover of tall scrub, whereas at the landscape scale there was a curvilinear relation, with occurrence of thrushes being highest when tall scrub made up $20 \%-25 \%$ of landscape cover (Fig. 4). Somewhat surprisingly, there was only moderate support for the inclusion of low scrub $(<6.5 \mathrm{~m}$ tall) at both the neighborhood and landscape scales (Table 2). However, when these terms were included in models, they both suggested a positive linear increase in probability of occurrence of thrushes with increasing cover of low scrub.

There was strong support for an influence of the cover of old growth forest at the landscape scale, where occurrence of thrushes was stable or slightly increasing up to $\sim 35 \%$ landscape cover and then declined (Fig. 4). However, we found no support for an influence of cover of old growth forest or 20- to 80-year-old second growth forest at the neighborhood scale on the occurrence of thrushes. There was weak support for an influence of cover of second growth forests at the landscape scale, where occurrence of thrushes was reduced as cover of second growth forests within $1250 \mathrm{~m}$ increased. There was also support for an influence of the amount of shoreline within $1250 \mathrm{~m}$ on occurrence of thrushes, although the pattern in the fit is complex and there was no support for a neighborhood effect. Occurrence of thrushes was approximately stable at low to moderate amounts of shoreline in the landscape, then showed a somewhat erratic decline as the incidence of shoreline increased further (Fig. 4).

Finally, there was strong support for the inclusion of three terms related to cover of managed forest types in our models. Occurrence of thrushes showed a curvilinear relation with the amount of 6- to 8 -year-old clearcut occurring within $115 \mathrm{~m}$ of survey points, where thrushes were most likely to be observed in neighborhoods having $60 \%-70 \%$ cover of clearcuts. In contrast, occurrence of thrushes was negatively related to the amount of clearcut at the $1250-\mathrm{m}$ scale (Fig. 4). Finally, there was a strong curvilinear relation between the probability of observing thrushes and the amount of modified forest harvesting within $115 \mathrm{~m}$. This term indicated that occurrence of thrushes increased rapidly up to $\sim 70 \%$ neighborhood cover of partially harvested stands and then declined. Although the pattern is very similar to that observed for neighborhood-scale clearcut, this finding should be interpreted with caution because only two modified harvest blocks were found in the study area and these were situated close together in a peripheral area where thrushes were relatively common (Fig. 2). Indeed 1589 of the 1613 survey points $(98.5 \%)$ had no modified harvest within $115 \mathrm{~m}$, raising concern that the observed association may have been coincidental.

\section{DISCUSSION}

One of the strongest and most striking patterns we saw in our study area was that Gray-cheeked Thrushes were restricted to elevations above $\sim 375 \mathrm{~m}$ and that occurrence increased at higher elevations (Fig. 5). Elevations in our study area only ranged from 300 to 600 
Fig. 4. Fitted relations between probability of occurrence and the continuous explanatory variables contained in our best model of habitat use by Gray-cheeked Thrushes (Catharus minimus minimus) in the Main River watershed, 2006 and 2007 (see Table 2). Smoothed values are plotted on the scale of the linear predictor (not the response variable) and are zero centered; the number following the covariate name in the y-axis label indicates the degrees of freedom (i.e., complexity) of the smoothed curve, where 1 equals a straight line, 2 indicates a quadratic curve, etc. Rugs along the horizontal (x) axis of each plot depict the individual observations used to fit that factor $(\mathrm{n}=1613)$. The rug along the horizontal axis of the mod.115 plot appears to have fewer observations because no modified harvesting occurred within $115 \mathrm{~m}$ of most survey points (i.e., there were 1589 observations having a value of zero).
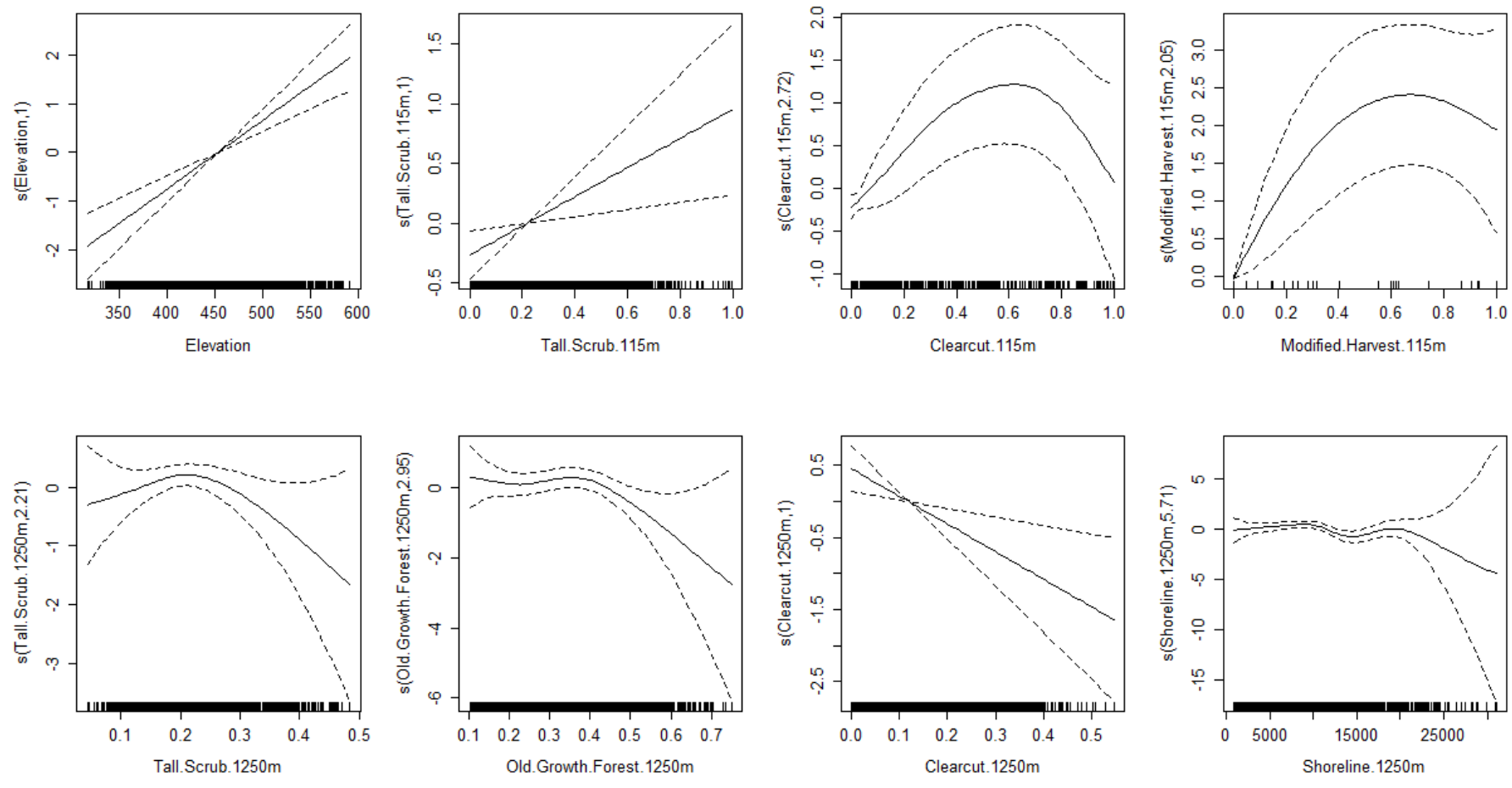

Fig. 5. Elevational distribution of Gray-cheeked Thrushes (Catharus minimus minimus) in the upper Main River and Humber River watersheds in western Newfoundland, 2006 and 2007. Survey points are grouped by 25 -m elevation classes, and the proportion of points where thrushes were observed is plotted at the midpoint of each class. The number of survey points in each elevation class is indicated next to each observation (total $=$ 1613).

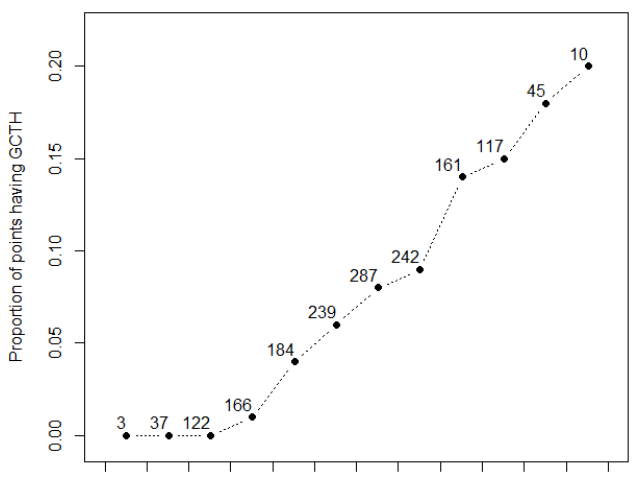

$\begin{array}{lllllllllllll}300 & 325 & 350 & 375 & 400 & 425 & 450 & 475 & 500 & 525 & 550 & 575 & 600\end{array}$

Elevation (m)

$\mathrm{m}$, but other bird surveys in the region complement our data in terms of the elevational range covered. During a study by Rae et al. (2015) at elevations ranging from 4 to $400 \mathrm{~m}$ in Gros Morne National Park, which is situated on the west slope of the Long Range Mountains $\sim 40 \mathrm{~km}$ west of our study area, this species was detected at just 5 of 596 point counts $(0.8 \%)$. In contrast, in 2014 fourteen territorial thrushes were observed nearby at elevations of 450-600 m along a 10-km route in the park highlands (Darroch M. Whitaker, unpublished data). This skew towards higher elevations is in sharp contrast to the distribution of Gray-cheeked Thrush in the park just a few decades ago, when they were one of the most abundant songbirds at low (and high) elevations (Lamberton 1976). For example, 22 and 26 individuals were recorded on a coastal BBS route in Gros Morne in 1974 and 1975, respectively (BBS route 57021; SSAC 2010). However, by the early 1990s this species had all but disappeared from park lowlands (Jacques Whitford 1993). Only five individuals were detected during five surveys of this BBS route in the 1990s, and none have been recorded during the eight surveys since 2000. Unfortunately the network of BBS routes in Newfoundland does not sample the higher elevations where we conducted our research, but does clearly show that thrushes have become extremely rare at lower elevations since the 1980s (SSAC 2010). These observations suggest that in western Newfoundland Gray-cheeked Thrushes 
may now be largely restricted to higher elevations and that this reflects the residual distribution of a collapsed population rather than selection for higher elevations per se. The inclusion of slope position in our best model adds some nuanced support to this finding, in that it appears that although the thrushes were more prevalent at higher elevations, they were more likely to occur on middle or lower slopes within these montane areas. Thus, they were not simply selecting a habitat type or feature associated with upper slopes or ridges.

The finding that Gray-cheeked Thrushes are now largely restricted to high elevations in western Newfoundland suggests that local factors may be important in the decline of this population (i.e., compared with factors acting during the nonbreeding period, which might affect individuals breeding in all areas of Newfoundland equally) and therefore may offer insight into the underlying causes of the population collapse. Although we did not record observations of red squirrels during our surveys, from 2002-2005 other researchers carried out squirrel live trapping at eight 4-ha survey plots located at elevations of $450-550 \mathrm{~m}$ in our study area and failed to capture a single squirrel (total 2880 trap nights; Gerrow and Gallant 2004, Gerrow et al. $2005,2006)$. This finding is in stark contrast to those from lower elevation forests throughout Newfoundland, where red squirrels are common or abundant (West 1989, Wren 2001, Lewis 2004). Similarly, in a study of nest depredation Thompson et al. (2008) reported that red squirrels were relatively common at lower elevations in our study area but were essentially absent at higher elevations. Related research on songbird nest success in our study area also reported that $82 \%$ of 169 nests fledged young, indicating that nest depredation rates were low (Dalley et al. 2009); this is also in agreement with the notion that impacts of squirrels on breeding birds were limited in this landscape. Thus, observations from our study area are consistent with the hypothesis that red squirrels have played a role in the decline of Gray-cheeked Thrushes on Newfoundland and suggest a mechanism underlying the thrushes' current, restricted distribution. The association of red squirrels with coniferous forest habitats is well known, although more detailed information on their distribution and habitat associations on Newfoundland and how these might interact with those of Gray-cheeked Thrushes and other boreal birds is lacking. However, because squirrels use vocalizations to defend their territories, they are regularly detected during bird surveys and may respond well to playbacks of conspecific vocalizations. Consequently, we encourage researchers to record squirrel observations during bird surveys in the boreal forest, because they may be an important factor influencing the abundance and distribution of thrushes and other species.

In terms of habitat use, our findings are in general agreement with reports by other authors that in Newfoundland Gray-cheeked Thrushes are often associated with various types of coniferous scrub forest (Lamberton 1976, Marshall 2001). This is not surprising because the species is widely reported to be associated with dense conifer cover including Krummholz (Godfrey 1986, Lowther et al. 2001). However, it is interesting that occurrence was more strongly linked to taller scrub classes; tall scrub stands in our study area were a mix of black spruce and fir having complex vertical structure with dense lower layers and sparse canopies. This finding may also suggest that Ouellet (1993) overstated the assertion that Newfoundland Gray-cheeked
Thrushes are usually found in mature coniferous stands and so have different habitat affinities from Bicknell's Thrushes, which prefer scrub and early successional forest (Rimmer et al. 2015).

This study supported the association of Newfoundland Graycheeked Thrushes with old growth fir forests reported by others (Lamberton 1976, Thompson et al. 1999, Marshall 2001), as well as avoidance of second growth forests as reported by Thompson et al. (1999). The curvilinear relationship we observed between thrush occurrence and landscape cover of old growth forest may reflect an affinity for landscapes characterized by a mixed-habitat matrix, where thrushes seek out areas having a moderate amount of old growth forest mixed with abundant scrub forest and possibly dense, early successional fir stands. However, it may also indicate that the species is only "tolerant of forest canopy if low shrub cover exists [in the understory]" (Lowther et al. 2001). Of note, we found two Gray-cheeked Thrush nests during the course of this study, and both were located in stands of old growth balsam fir.

Some factors retained in our best models were related to managed habitats. The finding of a curvilinear relation between the extent of clearcuts and occurrence of thrushes at the neighborhood scale appears to be at odds with the negative relation observed at the landscape scale, although we note that habitat occurring at the $115-\mathrm{m}$ scale accounted for less than $1 \%$ of cover within $1250 \mathrm{~m}$. We regularly observed Gray-cheeked Thrush in cutover habitats, and an associated passive mist netting study (Whitaker et al. 2008) resulted in 20 captures of the species at sites straddling the edges of these clearcuts compared with 25 captures from a similar amount of netting effort at sites located in naturally fragmented habitat. It is possible that Gray-cheeked Thrushes are tolerant of or even favor clearcuts and early successional forest at the neighborhood scale, but may be intolerant of large-scale harvesting occurring across the broader landscape. It may also be that they select mixed habitat, using either small clearcuts or selecting the edges of larger cutblocks, but avoid the centers of large clearcuts. However, an important caveat is that during this study all clearcuts were relatively young (6-8 years postharvest) and had only just begun to develop the dense regeneration of balsam fir saplings that is typical of older clearcuts in the region, so these areas may have only just begun to be colonized by thrushes. For comparison, Bicknell's Thrushes are also known to make extensive use of dense, young clearcuts dominated by balsam fir, but are most abundant in clearcuts 11-13 years postharvest (Nixon et al. 2001, Chisholm and Leonard 2008, Aubry et al. 2011). Although anecdotal, during subsequent research on Gray-cheeked Thrushes in our study area in 2013 and 2014, when these clearcuts would have been 13-15 years old, thrushes appeared to be more abundant and widespread in these same clearcuts and were observed in some clearcuts where they had not been seen in 2006 and 2007 (Darroch M. Whitaker, personal observation). Thus, findings related to use of 6- to 8-yearold clearcuts reported in this study need to be taken in context, realizing that patterns of use may change rapidly as clearcuts mature and the density of regenerating fir increases. This may be an important topic for future research.

We observed a strong curvilinear relation between the probability of detecting Gray-cheeked Thrushes and the amount of modified forest harvest (strip cut or partial cut) within $115 \mathrm{~m}$, but feel that 
this result should be interpreted with caution. Modified harvest blocks were limited and highly localized in our study area, raising concern that the observed association was coincidental. For example, these sites supported old growth forests when the modified harvesting occurred, so rather than selecting the area because of some novel character that resulted from partial harvesting, local birds may have remained simply because of site fidelity or some persisting feature of the residual stands. However, other authors have reported that open-canopy, mature forests can support the Gray-cheeked Thrush (Lamberton 1976, Thompson et al. 1999, Lowther et al. 2001), so it is possible that the modified cuts in our study area were favored because of their more open or broken canopies. Until further research is carried out, we suggest that the most basic interpretation be made of this finding, which is that thrushes will use old growth stands subject to modified harvesting.

\section{CONCLUSION}

Our study offers several insights into Gray-cheeked Thrush ecology and conservation. Perhaps most important was the observation of a strong association with high elevation habitats, because this may offer insight into the collapse of the Newfoundland population. Restriction of thrushes to higher elevation is consistent with the hypothesis that introduced red squirrels have played a role in the decline of thrushes in Newfoundland; therefore, focused research on the relation between squirrels and Gray-cheeked Thrushes seems warranted. It also suggests that the extent of the decline of this thrush in Newfoundland may be somewhat less than BBS data suggest (e. g., SSAC 2010), because all BBS routes on the island are found at lower elevations. However less than $14 \%$ of Newfoundland exceeds 375-m elevation and much of this area consists of barren Arctic-alpine habitats that do not support thrushes, so the assessment that most of the island's Gray-cheeked Thrush population has disappeared remains valid.

Another important observation is that the Newfoundland Graycheeked Thrush appears to be a mixed-habitat species that responds to both local and landscape scale features. This was evident in the number of neighborhood and landscape-scale habitat types with which the species' occurrence showed positive or curvilinear relations (Fig. 4). At a neighborhood scale a curvilinear association likely suggests selection for patches of an intermediate size, or use of areas near the edge of larger patches. At the landscape scale this pattern of occurrence indicates selection for landscapes containing intermediate amounts of a landcover type. This observation accords with that of Marshall (2001), who searched extensively for the species in Newfoundland and concluded that it was "capricious" in its choice of habitat, occupying riparian, coastal, and timberline conifer scrub and tall spruce and fir forest. Gray-cheeked Thrushes were also sensitive to habitat factors occurring at a landscape scale. A plethora of recent studies have demonstrated that breeding boreal forest songbirds typically make daily movements on a scale of hundreds of meters to kilometers and respond directly to habitat at this scale (Whitaker and Warkentin 2010). Along these lines we observed a banded Gray-cheeked Thrush at a survey point $4 \mathrm{~km}$ from the nearest location where we had banded this species, suggesting that at least on occasion thrushes make landscapescale movements on the breeding grounds. Consequently, it will be important to consider the structure of the broader landscape when developing conservation guidelines for this species in Newfoundland, particularly in relation to forest management.

Finally, our results indicate that forest management could play an important role in the conservation and recovery of the Graycheeked Thrush in Newfoundland. Most obviously, more detailed information on responses of thrushes to clearcutting might lead to management prescriptions that support or benefit thrushes. Another silvicultural practice that may warrant investigation is precommercial thinning, which dramatically reduces the suitability of young, regenerating clearcuts as breeding habitat for Bicknell's Thrush (Chisholm and Leonard 2008, Aubry et al. 2011) and may have similar consequences for Gray-cheeked Thrushes. Precommercial thinning became widespread in Newfoundland during the 1990s, when 7000 ha of clearcuts were thinned annually (Government of Newfoundland and Labrador 2014). This was also the period when Gray-cheeked Thrush populations were in free fall, although this may have been coincidental. However, because of a downturn in the pulp and paper industry on the island, the incidence of precommercial thinning dropped to just 526 ha in 2013. Thus, although precommercial thinning may have played a role in the decline of Gray-cheeked Thrushes in Newfoundland, the influence of this practice may be limited at present. Finally, although not currently widely practiced in Newfoundland, our study indicates that thrushes can also persist in high numbers in partially harvested cutblocks (strip cuts and row cuts) located in old growth fir stands. Research into these forest-harvesting techniques may allow the identification of the most beneficial management prescriptions in areas where Gray-cheeked Thrushes persist, such as higher elevations in the Long Range Mountains.

Responses to this article can be read online at: http://www.ace-eco.org/issues/responses.php/778

\section{Acknowledgments:}

Daniel Gelynse, Tina Leonard, Greg Mitchell, Karen Odum, and Brad Woodworth assisted with bird surveys, Scott Taylor helped with GIS data processing, and Dan Kehler offered advice on data analysis. Kent McFarland first suggested that we consider the role that red squirrels may have played in the decline of Newfoundland's Gray-cheeked Thrush population. Research funding and other support were provided by the Natural Sciences and Engineering Research Council of Canada, Corner Brook Pulp and Paper, the Humber River Basin Project of Memorial University, and Gros Morne National Park of Canada.

\section{LITERATURE CITED}

Aubry, Y., A. Desrochers, and G. Seutin. 2011. Response of Bicknell's Thrush (Catharus bicknelli) to boreal silviculture and forest stand edges: a radio-tracking study. Canadian Journal of Zoology 89:474-482. http://dx.doi.org/10.1139/z11-011

Bartoń, K. 2015. MuMIn: Multi-Model Inference. R package version 1.13.4. R Project for Statistical Computing, Vienna, Austria. [online] URL: http://CRAN.R-project.org/package= MuMIn 
Betts, M. G., L. Fahrig, A. S. Hadley, K. E. Halstead, J. Bowman, W. D. Robinson, J.A. Weins, and D. B. Lindenmayer. 2014. A species-centered approach for uncovering generalities in organism responses to habitat loss and fragmentation. Ecography 37:517-527. http://dx.doi.org/10.1111/ecog.00740

Betts, M. G., A. S. Hadley, and P. J. Doran. 2005. Avian mobbing response is restricted by territory boundaries: experimental evidence from two species of forest warblers. Ethology 111:821-835. http://dx.doi.org/10.1111/j.1439-0310.2005.01109. $\mathrm{x}$

Burnham K. P., and D. R. Anderson, editors. 2002. Model selection and multimodel inference. Second edition. Springer, New York, New York, USA. http://dx.doi.org/10.1007/b97636

Chisholm, S. E., and M. L. Leonard. 2008. Effect of forest management on a rare habitat specialist, the Bicknell's Thrush (Catharus bicknelli). Canadian Journal of Zoology 86:217-223. http://dx.doi.org/10.1139/Z07-131

Dalley, K. L., P. D. Taylor, and D. Shutler. 2009. Success of migratory songbirds breeding in harvested boreal forests of northwestern Newfoundland. Condor 111(2):314-325. http://dx. doi.org/10.1525/cond.2009.080104

Dodds, D. 1983. Terrestrial mammals. Pages 163-206 in G. R. South, editor. Biogeography and ecology of the island of Newfoundland. Dr. W. Junk Publishers, The Hague, Netherlands.

Environment Canada. 2014. North American breeding bird survey-Canadian trends website. Data-version 2012. Environment Canada, Gatineau, Quebec, Canada. [online] URL: http://www.ec.gc.ca/ron-bbs/P001/A001/?lang=e

Gerrow, J. S., and T. Gallant. 2004. Monitoring the effectiveness of different forest harvesting methods for maintaining marten habitat in the Main River Watershed. Progress Report (June 2003-May 2004). Parks Canada, Rocky Harbor, Newfoundland and Labrador, Canada.

Gerrow, J. S., T. Gallant and R. Reid. 2005. Monitoring the effectiveness of different forest harvesting methods for maintaining marten habitat in the Main River Watershed. Progress Report (June 2004-April 2005). Parks Canada, Rocky Harbor, Newfoundland and Labrador, Canada.

Gerrow, J. S., T. Gallant, and R. Reid. 2006. Monitoring the effectiveness of different forest harvesting methods for maintaining marten habitat in the Main River Watershed. Progress Report (June 2005-April 2006). Parks Canada, Rocky Harbor, Newfoundland and Labrador, Canada.

Godfrey, W. E. 1986. The birds of Canada. Revised edition. National Museums of Canada, Ottawa, Ontario, Canada.

Goudie, R.I. 1978. Red squirrels, Tamiasciurus hudsonicus, in the Salmoneir River Valley, Newfoundland. Canadian Field Naturalist 92:193-194.

Government of Newfoundland and Labrador. 2014. Growing our renewable and sustainable forest economy: provincial sustainable forest management strategy, 2014-2024. Newfoundland and Labrador Department of Natural Resources, St. John's,
Newfoundland and Labrador, Canada. [online] URL: http:// www.nr.gov.nl.ca/nr/pdf/psfms_171114.pdf

Gunn J. S., A. Desrochers, M.-A. Villard., J. Borque, and J. Ibarzabal. 2000. Playbacks of mobbing calls of black-capped chickadees as a method to estimate reproductive activity of forest birds. Journal of Field Ornithology 71(3):472-483. http:// dx.doi.org/10.1648/0273-8570-71.3.472

Jacques Whitford. 1993. Avifaunal inventory, Gros Morne National Park. Report to Parks Canada, Rocky Harbor, Newfoundland and Labrador, Canada.

Johnson, D. H. 1980. The comparison of usage and availability measurements for evaluating resource preference. Ecology 61:65-71. http://dx.doi.org/10.2307/1937156

Lambert, D. J., K. P. McFarland, C. C. Rimmer, S. D. Faccio, and J. L. Atwood. 2005. A practical model of Bicknell's Thrush distribution in the northeastern United States. Wilson Bulletin 117(1):1-11. http://dx.doi.org/10.1676/04-013

Lamberton, R. D. 1976. Avifaunal survey of Gros Morne National Park. Parks Canada, Rocky Harbor, Newfoundland and Labrador, Canada.

Lee, M., L Fahrig, K. Freemark, and D. J. Currie. 2002. Importance of patch scale vs landscape scale on selected forest birds. Oikos 96:110-118. http://dx.doi.org/10.1034/

j.1600-0706.2002.960112.x

Leonard, T. D., P. D. Taylor, and I. G. Warkentin. 2008. Landscape structure and spatial scale affect space use by songbirds in naturally patchy and harvested boreal forests. Condor 110:467-481. http://dx.doi.org/10.1525/cond.2008.8512

Lewis, K. P. 2004.Processes underlying nest predation by introduced red squirrels (Tamiasciurus hudsonicus) in the boreal forest of Newfoundland. Dissertation. Memorial University of Newfoundland, St. John's, Newfoundland and Labrador, Canada.

Lowther, P. E., C. C. Rimmer, B. Kessel, S. L. Johnson, and W. G. Ellison. 2001. Gray-cheeked Thrush (Catharus minimus). In A. Poole, editor. The birds of North America online. Cornell Lab of Ornithology, Ithaca, New York, USA. [online] URL: http:// bna.birds.cornell.edu/bna/species/591

Marshall, J. T. 2001. The gray-cheeked thrush Catharus minimus, and its New England subspecies, Bicknell's thrush, Catharus minimus bicknelli. No. 28. Nuttall Ornithological Club, Buteo Books, Arrington, Virgina, USA.

McCarthy, J. W., and G. Weetman. 2006. Age and size structure of gap-dynamic, old-growth boreal forest stands in Newfoundland. Silva Fennica 40:209-230. http://dx.doi. org/10.14214/sf.339

McFarland, K. P., C. C. Rimmer, S. J. K. Frey, S. D. Faccio, and B. B. Collins. 2008. Demography, ecology and conservation of Bicknell's Thrush in Vermont, with a special focus on the Northeast Highlands. Technical Report 08-03. Vermont Center for Ecostudies, Norwich, Vermont, USA. [online] URL: http:// m.vtecostudies.org/PDF/VCEBITHReport2008.pdf 
Minty, D. 1976. Red squirrels in Newfoundland. OspreyNewfoundland Natural History Society Quarterly 7(1):19-24.

Mitchell, G. W., P. D. Taylor, and I. G. Warkentin. 2010. Multiscale postfledging habitat associations of juvenile songbirds in a managed landscape. Auk 127:354-363. http://dx. doi.org/10.1525/auk.2009.09060

Mitchell G. W., I. G. Warkentin, and P. D. Taylor. 2009. Movement of juvenile songbirds in harvested boreal forest: assessing residency time and landscape connectivity. Avian Conservation and Ecology 4(1):5. [online] URL: http://www.aceeco.org/vol4/iss1/art5/

Nixon, E. A., S. B. Holmes, and A. W. Diamond. 2001. Bicknell's Thrushes (Catharus bicknelli) in New Brunswick clear cuts: their habitat associations and co-occurrence with Swainson's Thrushes (Catharus ustulatus). Wilson Bulletin 113:33-40. http:// dx.doi.org/10.1676/0043-5643(2001)113[0033:BTCBIN]2.0.CO;2

Ouellet, H. 1993. Bicknell's Thrush: taxanomic status and distribution. Wilson Bulletin 105:545-572.

Payne, N. 1976. Red squirrel introduction to Newfoundland. Canadian Field Naturalist 90:60-64.

Powell, R. A. 2000. Animal home ranges and territories and home range estimators. Pages 65-110 in L. Boitani and T. K. Fuller, editors. Research techniques in animal ecology. Columbia University Press, New York, New York, USA.

R Development Core Team. 2015. R: a language and environment for statistical computing. R Project for Statistical Computing, Vienna, Austria. [online] URL: http://www.R-project.org/

Rae, L. F., D. M. Whitaker and I. G. Warkentin. 2015. Variable effect of chickadee mobbing call playback on detection probability of boreal forest birds. Journal of Field Ornithology 86(1):51-64. http://dx.doi.org/10.1111/jofo.12088

Riffell, S. K., and B. D. Riffell. 2002. Can observer clothing color affect estimates of richness and abundance? An experiment with point counts. Journal of Field Ornithology 73:351-359. http://dx.doi.org/10.1648/0273-8570-73.4.351

Rimmer, C. C., K. P. McFarland, J. Townsend, W. G. Ellison, and J. E. Goetz. 2015. Bicknell's Thrush (Catharus bicknelli). In A. Poole, editor. The birds of North America online. Cornell Lab of Ornithology, Ithaca, New York, USA. [online] URL: http:// bna.birds.cornell.edu/bna/species/592

Sauer, J. R., J. E. Hines, J. E. Fallon, K. L. Pardieck, D. J. Ziolkowski, Jr., and W. A. Link. 2014. The North American Breeding Bird Survey, results and analysis 1966-2013. Version 01.30.2015. USGS Patuxent Wildlife Research Center, Laurel, Maryland, USA.

Species Status Advisory Committee (SSAC) 2010. The status of Gray-cheeked Thrush (Catharus minimus) in Newfoundland and Labrador. Report No. 24. Species Status Advisory Committee, St. John's, Newfoundland and Labrador, Canada. [online] URL: http://www.env.gov.nl.ca/env/wildlife/endangeredspecies/ssac/Graycheeked_Thrush_2010_SSAC.pdf
Symonds, M. R. E., and A. Mousalli. 2011. A brief guide to model selection, multimodel inference and model averaging in behavioural ecology using Akaike's information criterion. Behavioural Ecology and Sociobiology 65:13-21. http://dx.doi. org/10.1007/s00265-010-1037-6

Taylor, P. D., and M. A. Krawchuk. 2005. Scale and sensitivity of songbird occurrence to landscape structure in a harvested boreal forest. Avian Conservation and Ecology 1(1):5. [online] URL: http://www.ace-eco.org/vol1/iss1/art5/

Thompson, I. D. 1991. Could marten become the spotted owl of eastern Canada? Forestry Chronicle 67:136-140. http://dx.doi. org/10.5558/tfc67136-2

Thompson, I. D., H. A. Hogan, and W. A. Montevecchi. 1999. Avian communities of mature balsam fir forests in Newfoundland: age dependence and implications for timber harvesting. Condor 101:311-323. http://dx.doi.org/10.2307/1369994

Thompson, I. D., D. J. Larson and W. A. Montevecchi. 2003. Characterization of old "wet boreal" forest, with an example from balsam fir forests of western Newfoundland. Environmental Reviews 11:S23-S46. http://dx.doi.org/10.1139/ a03-012

Thompson, R. G., I. G. Warkentin, and S. P. Flemming. 2008. Response to logging by a limited but variable nest predator guild in the boreal forest. Canadian Journal of Forest Research 38:1974-1982. http://dx.doi.org/10.1139/X08-049

Vassallo, M. I., and J. C. Rice. 1981. Differential passerine density and diversity between Newfoundland and offshore Gull Island. Wilson Bulletin 93(3):340-349.

West, R. J. 1989. Cone depredation by the red squirrel in black spruce stands in Newfoundland: implications for commercial cone collection. Canadian Journal of Forest Research 19:1207-1210. http://dx.doi.org/10.1139/x89-182

Whitaker, D. M., D. F. Stauffer, G. W. Norman, P. K. Devers, T. J. Allen, S. Bittner, D. Buehler, J. Edwards, S. Friedhoff, W. M. Giuliano, C. A. Harper, and B. Tefft. 2006. Factors affecting habitat use by Appalachian ruffed grouse. Journal of Wildlife Management 70(2):460-471. http://dx.doi.org/10.2193/0022-541x (2006)70[460:fahuba]2.0.co;2

Whitaker, D. M., P. D. Taylor, and I. G. Warkentin. 2008. Survival of adult songbirds in boreal forest landscapes fragmented by clearcuts and natural openings. Avian Conservation and Ecology 3(1):5. [online] URL: http://www.aceeco.org/vol3/iss1/art5/

Whitaker, D. M., and I. G. Warkentin. 2010. Spatial ecology of migratory passerines on temperate and boreal forest breeding grounds. Auk 127(3):471-484. http://dx.doi.org/10.1525/ auk.2010.127.3.471

Wood, S. N. 2011. Fast stable restricted maximum likelihood and marginal likelihood estimation of semiparametric generalized linear models. Journal of the Royal Statistical Society: Series $B$ 73(1):3-36. http://dx.doi.org/10.1111/ j.1467-9868.2010.00749.x 
Wren, L. S. 2001. Continental and regional distribution and abundance patterns of boreal cardueline finches: influences of conifer seed availability. Thesis. Memorial University of Newfoundland, St. John's, Newfoundland and Labrador, Canada.

Zuur, A. F., E. N. Ieno, N. J. Walker, A. A. Saveliev, and G. M. Smith. 2009. Mixed effects models and extensions in ecology with $R$. Springer, New York, New York, USA. http://dx.doi. org/10.1007/978-0-387-87458-6 